\title{
PENYULUHAN KESEHATAN DENGAN METODE BRAINSTORMING DAN SIMULATION GAME TERHADAP PENGETAHUAN REMAJA PEREMPUAN TENTANG MENSTRUASI
}

\author{
Novita Br Ginting Munthe ${ }^{1 *}$, Iskandar Markus Sembiring ${ }^{2}$, Sri Wulan ${ }^{1}$, Rahmad \\ Gurusinga², Diah Evawanna Anuhgera ${ }^{1}$ \\ ${ }^{1}$ Fakultas Kebidanan, Institut Kesehatan Medistra Lubuk Pakam \\ ${ }^{2}$ Fakultas Keperawatan dan Fisioterapi, Institut Kesehatan Medistra Lubuk Pakam \\ Jln. Sudirman No.38 Lubuk Pakam, Kabupaten Deli Serdang, \\ Sumatera Utara - Indonesia \\ *email korespondensi author: novitagintingmunthe89@gmail.com
}

DOI $10.35451 /$ jpk.v1i1.729

\begin{abstract}
Abstrak
Menstruasi merupakan pendarahan yang dipengaruhi oleh hormon dalam tubuh dan berkaitan dengan organ yang ada dalam tubuh (hipotalamus, hipofisis, uterus, dan ovarium) disertai deskuamasi secara siklis/periodik. Pada dasarnya setiap wanita yang menstruasi memiliki siklus yang berbeda dengan wanita lainnya. Hal tersebut bisa saja dipengaruhi oleh kondisi fisik setiap wanita yang berbeda, faktor genetik(keturunan), indeks massa tubuh, hormonal, tingkat stres, dan gaya hidup yang tidak baik. Kelompok remaja harus menjadi perhatian dengan alasan selain dari jumlah mereka yang sangat besar juga rentan terhadap risiko gangguan kesehatan di bagian organ reproduksinya. Peningkatan pengetahuan melalui penyuluhan kesehatan disaat masa remaja merupakan salah satu cara untuk mencapai kesehatan reproduksi remaja puteri yang sehat. Peningkatan pengetahuan melalui penyuluhan kesehatan akan memberikan berdampak positif apabila prosesnya menggunakan suatu media ataupun metode yang terarah dan baik. Salah satu metode dalam penyuluhan kesehatan adalah dengan metode simulation game dan brain storming. Tujuan dari penulisan ini yaitu untuk memberikan penyuluhan kesehatan antara metode brainstorming dan simulation game terhadap peningkatan pengetahuan mengenai menstruasi. Peserta dalam penyuluhan Kesehatan adalah siswi kelas $X$ di SMA Negeri Beringin berjumlah 66 orang. Pada pelaksanaan kegiatan menggunakan kuisioner untuk mengumpulkan data peserta penyuluhan berdasarkan tingkat pengetahuan tentang menstruasi. Kesimpulan dari kegiatan ini bahwa penyuluhan kesehatan dengan menggunakan metode simulation game dan brain storming mampu menstimulus peningkatan pengetahuan remaja puteri mengenai menstruasi.
\end{abstract}

Kata kunci: Penyuluhan Kesehatan, Menstruasi, brainstorming, Simulation Game, Pengetahuan

\begin{abstract}
Menstruation is bleeding that is influenced by hormones in the body and related to organs in the body (hypothalamus, pituitary, uterus, and ovaries) accompanied by cyclical/periodic desquamation. Basically every woman who menstruates has a different cycle with other women. This can be influenced by the physical condition of each woman who is different, genetic factors (heredity), body mass index, hormones, stress levels, and an unhealthy lifestyle. Adolescent groups must be a concern for reasons other than their very large number, they are also vulnerable to the risk of health problems in their reproductive organs. Increasing knowledge through health counseling during adolescence is one way to achieve healthy reproductive health for young women. Increased knowledge through health education will have a positive impact if the process uses a directed and good media or method. One of the methods
\end{abstract}


Received: 07 June 2021 :: Accepted: 24 June 2021 :: Published: 30 June 2021

in health education is the simulation game method and brain storming. The purpose of this paper is to provide health education between brainstorming methods and simulation games to increase knowledge about menstruation. The participants in the Health education were 66 grade $X$ students at SMA Negeri Beringin. In the implementation of the activity, questionnaires were used to collect data on counseling participants based on their level of knowledge about menstruation. The conclusion of this activity is that health education using the simulation game and brain storming methods is able to stimulate the increase in knowledge of young women about menstruation.

Keywords: Health Counseling, Menstruation, brainstorming, Simulation Game, Knowledge

\section{Pendahuluan}

Sebelum mengalami menstruasi pertama kali atau sering disebut dengan menarche, remaja puteri mebutuhkan suatu konseling, edukasi, dan informasi terkait menstruasi secara lengkap atau memadai. Dengan demikian remaja puteri akan mengerti perubahan yang akan terjadi dalam dirinya, sehingga mereka tidak merasa khawatir atau terkejut saat mengalami haid pertama sekali. Yang perlu diperhatikan juga adalah konseling, informasi, dan edukasi yang diberikan harus dipertimbangkan kedalaman materi terkait menstruasi, sehingga remaja puteri merasa tentram, nyaman, dan sesuai dengan tingkat kedewasaan mereka (Ernawati Sinaga, dkk, 2017).

Salah satu peristiwa penting yang di alami setiap remaja puteri adalah menstruasi yang berkaitan dengan kesehatan reproduksinya. Maka sangat penting untuk diperhatikan dari segi aspek kesehatan. Selain dari aspek kesehatan remaja puteri yang menjadi perhatian juga adalah aspek kesehatan fisik, mentalitas, spritual, serta sosial. Setiap wanita perlu mengetahui dan memahami bagaimana jarak dan pola masing-masing dari menstruasi, sehingga mampu memperhatikan dan menilai jika ada terjadi di luar kebiasaan yang arahnya patologis. Menjaga kebersihan dan kesehatan saat menstruasi wajib diperhatikan untuk menghindari masuknya kuman ke bagian organ reproduksi (Sri Lestari Kartikawati, 2016 dan Yuni, E, N., 2015).
Penelitian United Nations Emergency Children's Fund (UNICEF) pada tahun 2015 menyebutkan bahwa telah terjadi peningkatan kesadaran akan dampak praktik pengelolaan menstruasi terhadap pendidikan, kesehatan, dan psikososial bagi remaja puteri dan wanita di negara dengan berpenghasilan mulai dari tingkar rendah sampai menengah. Penelitian yang telah dilakukan di negara bagian Afrika, Asia, dan Amerika Latin menjelaskan bahwa wanita akan menghadapi tantangan, seperti keterbatasan dalam mengakses informasi yang lengkap mengenai menstruasi, rendahnya pengetahuan dalam pengelolaan darah menstruasi, ketidakcukupan sanitasi, air, dan fasilitas yang tidak mendukung, adanya pantanganyang dianggap masih tabu, serta keyakinan sosial dan budaya yang dianggap menyesatkan. Sakit yang timbul dari gejala menstruasiseperti pusing, lemas, dan lesumenyebakan partisipasi remaja puteri di sekolah menurun. Satu dari tujuh remaja putri tidak masuk ke sekolah satu hari atau lebih saat menstruasi (Sri Ayu Maharani, Linda Ratna Wati, dan Yuseva Sariati, 2019). Penelitian Unicef memperlihatkan bahwa sebagian besar remaja putri menggunakan pembalut sekali pakai saat menstruasi, yaitu lebih dari $99 \%$ peserta di daerah urban dan lebih dari $97 \%$ peserta di daerah rural yang menggunakan pembalut sekali pakai. Untuk pembalut cuci ulang yang terbuat dari kain, di daerah rural 9.6\% dan urban $5.5 \%$ peserta yang 
menggunakannya. Khusus remaja putri di Sulawesi Selatan, hasil penelitian menunjukkan 14\% menggunakan kain disaat menstruasi yang terakhir dibandingan dengan remaja putri di provinsi lain. Remaja puteri lebih menyukai pembalut sekali pakai dari pada kain dalam mengatasi pendarahan saat menstruasi dengan alasan lebih menyerap, mudah dan praktis digunakan, serta mudah untuk dibuang. Beberapa remaja puteri juga menyatakan bahwa mereka tidak merasa nyaman menggunakan pembalut karena dapat menyebabkan timbul gatal dan iritasi. Beberapa remaja puteri mengasumsi bahwa setiap pembalut mengandung bahan kimia dan pemutih dan yang dapat menyebabkan suati penyakit seperti kanker dan iritasi yang parah. Hanya dua pertiga remaja puteri di daerah perkotaan dan kurang dari setengah $(41 \%)$ remaja puteri di daerah rural yang mengganti pembalut setidaknya setiap 4-8 jam sekali atau atau setiap kali kotor. Sisanya, $46 \%$ remaja putri mengganti pembalut kurang dari dua kali sehari. Penggantian pembalut terendah terjadi di kalangan remaja puteri NTT yaitu hanya $31 \%$ yang mengganti pembalut dalam rentang 4-8 jam atau jika sudah dianggap penuh atau kotor. Selain rendahnya partisipasi di sekolah dan dalam setiap kegiatan yang ada, praktik dan tantangan yang dihadapi oleh remaja puteri di sekolah juga memiliki risiko kesehatan yaitu timbulnya infeksi karena kurangnya kebiasaan dalam mencuci tangan dan kurang bersihnya kain yang dipakai saat menstruasi (Ernawati Sinaga, dkk., 2017).

Manajemen kebersihan dalam menstruasi merupakan suatu pengelolaan kebersihan dan kesehatan saat mengalami menstruasi. Setiap wanita harus dapat menggunakan pembalut yang hygiene dan mengganti sesering mungkin diri, sehingga timbul kondisi nyaman, sehat, dan terjaga (Kusmiran, 2012).

Penyuluhan kesehatan merupakan kegiatan yang memperhatikan prinsip suatu pembelajarandengan tujuan mencapai keadaan ingin hidup sehat dan mengetahui upaya yang dapat dilakukan agar terciptanya hidup yang sehat. Brain Storming (curah pendapat) adalah modifikasi dari suatu metode diskusi kelompok yang memiliki prinsip yang sama tetapi memiliki suatu perbedaan d pada. Setiap diawal diskusi berlangsung setiap pimpinan kelompok memancing peserta dengan menyatakan sebuah permasalahan, setelah itu tiap peserta memberikan komentar, tanggapan atau jawaban ataupun dari permasalahan tersebut (Aulia, 2016; Maharani, dkk. 2019 dan Rama Wahyu Rusinto, 2019). Sedangkan untuk Simulation Game (SIG) adalah modifikasi dari suatu permainan simulasi, dimana setiap peserta akan melakukan suatu permainan roda putar dan di dalamnya terdapat informasi-informasi mengenai menstruasi (Makarao, N. Ramadani., 2009; Muh. Zaidi Thahir, 2017 dan Dwi Wahyuni, 2017).

\section{Metode}

Metode yang diterapkan pada kegiatan pengabdian kepada masyarakat (PKM) yaitu dengan menggunakan lembar observasi dan membagikan kusioner setelah pemberian penyuluhan kesehatan. Penyuluhan Kesehatan dengan metode brainstorming dan simulation game. Kegiatan PKM dilakukan di SMA negeri 1 Beringin Kecamatan Sidodadi Kabupaten Deli Serdang, yang menjadi sasaran dalam kegiatan ini adalah para para siswi SMA sebanyak 66 orang.

\section{Hasil dan Pembahasan}

Penyuluhan Kesehatan dengan metode brainstorming dan simulation game.

Tabel 1. Distribusi Frekuensi Sebelum Diberikan Penyuluhan Brainstorming Terhadap Pengetahuan Remaja Puteri Tentang Menstruasi

\begin{tabular}{cccc}
\hline \multicolumn{4}{c}{$\begin{array}{c}\text { Sebelum } \\
\text { Brainstorming } \\
\text { terhadap }\end{array}$} \\
po & $\mathrm{N}$ & $\%$ \\
\hline 1 & Cukup $(56 \%-75 \%)$ & 17 & 25,8 \\
2 & Kurang $(<56 \%)$ & 16 & 24,2 \\
\hline & Total & 33 & 50,0 \\
\hline
\end{tabular}


Received: 07 June 2021 :: Accepted: 24 June 2021 :: Published: 30 June 2021

Dari tabel 1 dapat dilihat bahwa pada kategori sebelum penyuluhan brainstorming terhadap pengetahuan remaja tentang menstruasi didapatkan hasil pada kategori cukup (56-75\%) sebanyak 17 siswi dan kurang $(<56 \%)$ sebanyak 16 siswi. Bisa ditarik kesimpulan yang menjadi mayoritas peserta adalah pada kategori cukup.

Tabel 2. Distribusi Frekuensi Sesudah diberikan Penyuluhan Brainstorming

Terhadap Pengetahuan Remaja Puteri Tentang Menstruasi

\begin{tabular}{|c|c|c|c|}
\hline No & $\begin{array}{c}\text { Sesudah } \\
\text { Brainstorming } \\
\text { terhadap } \\
\text { pengetahuan } \\
\text { remaja }\end{array}$ & $\mathrm{N}$ & $\%$ \\
\hline 1 & Baik (76\%-100\%) & 24 & 36,4 \\
\hline \multirow[t]{2}{*}{2} & Cukup (56\%-75\%) & 9 & 13,6 \\
\hline & Total & 33 & 50,0 \\
\hline
\end{tabular}

Dari tabel 2 dapat dilihat bahwa Pada kategori sesudah penyuluhan brainstorming terhadap pengetahuan remaja tentang menstruasi didapatkan hasil pada kategori baik (76-100\%) sebanyak 24 siswi dan cukup (56-75\%) sebanyak 9 siswi. Bisa ditarik kesimpulan yang menjadi mayortitas peserta adalah pada kategori baik.

Tabel 3. Distribusi Frekuensi Sebelum diberikan Penyuluhan Simulation game Terhadap Pengetahuan Remaja Puteri Tentang Menstruasi

Sebelum

\begin{tabular}{ccc}
\hline \multicolumn{3}{c}{ Sebelum } \\
Simulation game \\
terhadap \\
pengetahuan \\
remaja
\end{tabular}

\begin{tabular}{llll}
\hline 1 Cukup (56\%-75\%) & 13 & 19,7 \\
2 & Kurang (<56\%) & 20 & 30,3 \\
\hline Total & 33 & 50,0 \\
\hline \multicolumn{2}{c}{ Dari tabel 3 dapat dilihat } & bahwa
\end{tabular}

Pada kategori sebelum penyuluhan simulation game terhadap pengetahuan remaja tentang menstruasi didapatkan hasil pada kategori cukup (56-75\%) sebanyak 13 siswi dan kurang $(<56)$ sebanyak 20 siswi. Bisa ditarik kesimpulan yang menjadi mayoritas peserta adalah pada kategori kurang.
Tabel 4. Distribusi Frekuensi Sesudah diberikan Penyuluhan Simulation game Terhadap Pengetahuan Remaja Puteri Tentang Menstruasi

\begin{tabular}{cccc}
\hline No & $\begin{array}{c}\text { Sesudah Simulation } \\
\text { game terhadap } \\
\text { pengetahuan remaja }\end{array}$ & N & $\%$ \\
\hline 1 & Baik $(76 \%-100 \%)$ & 22 & 33,3 \\
2 & Cukup $(56-75 \%)$ & 8 & 12,1 \\
3 & Kurang $(<56)$ & 3 & 4,5 \\
\hline & Total & 33 & 50,0 \\
\hline
\end{tabular}

Dari tabel 4 dapat dilihat bahwa pada kategori sesudah penyuluhan simulation game terhadap pengetahuan remaja tentang menstruasi didapatkan hasil pada kategori baik (76-100\%) sebanyak 22 siswi, kategori cukup (56$75 \%)$ sebanyak 8 siswi dan kurang $(<56 \%)$ sebanyak 3 siswi. Bisa ditarik kesimpulan yang menjadi mayortitas peserta adalah pada kategori baik.

Keberhasilan dari penyuluhan kesehatan pada PKM ini dipengaruhi oleh metode yang sesuai dengan besarnya kelompok sasaran sehingga proses penyelenggaraan yang dilakukan pada saat penyuluhan kesehatan dapat lebih meningkatkan rasa ketertarikan remaja puteri dalam mengikuti kegiatan penyuluhan tersebut. Metode yang digunakan (brain storming dan simulation game) sangat efektif dan membuat peserta lebih fokus..

Kedua metode tersebut dapat meningkatkan pengetahuan remaja puteri dikarenakan terdapat proses berfikir atau bertukar informasi terkait menstruasi yang terjadi pada saat penyuluhan kesehatan. Kedua metode tersebut efektif dalam meningkatkan pengetahuan para remaja puteri (siswi) mengenai menstruasi. Berdasarkan hasil post test metode simulation game lebih efektif dalam peningkatkan pengetahuan remaja dibandingkan dengan metode brain storming.

\section{Kesimpulan}

Berdasarkan hasil kegaitan pengabdian kepada masyarakat dapat disimpulkan bahwa Terdapat perbedaan frekuensi pengetahuan sebelum (prettest) dan sesudah (posttest) 
Received: 07 June $2021::$ Accepted: 24 June 2021 :: Published: 30 June 2021

dilakukannya penyuluhan metode brainstorming terhadap pengetahuan remaja perempuan tentang menstruasi di SMA Negeri 1 Beringin Kecamatan Sidodadi Ramunia Kabupaten Deli Serdang.

\section{Ucapan Terima Kasih}

Ucapan terima kasih disampaikan kepada Institut Kesehatan Medistra Lubuk Pakam dan kepala sekolah SMA Negeri 1 Beringin Kecamatan Sidodadi Ramunia Kabupaten Deli Serdang,semua siswi SMA serta semua pihak yang membantu dalam kegiatan PKM ini, semoga PKM ini bermanfaat untuk semua pembaca.

\section{Daftar Pustaka}

Aulia. (2016). Penerapan metode tanya jawab dalam bentuk roda keberuntungan untuk meningkatkan hasil belajar siswa pada mata pelajaran PAI di SMP Seri Tanjung Kabupaten Ogan Hilir (skripsi): https://eprints.radenfatah.ac.id

Dwi Wahyuni. (2017). Pengaruh penggunaan media permainan roda keberuntungan terhadap kemampuan menulis hanzi pada siswa kelas XI bahasa SMA Negeri 1 cerme tahun ajaran 2016/2017 : https://jurnalmahasiswa.unesa.ac. id diakses pada : 22 Maret 2021

Ernawati Sinaga, dkk. (2017). E-Book Manajemen Kesehatan Mestruasi, Universitas Nasional, IWWASH, Global One.

Kusmiran, Eny. (2012). Kesehatan Reproduksi Remaja dan Wanita. Jakarta : Salemba Medika

Makarao, N. Ramadani. (2009). Metode mengajar dalam bidang kesehatan. Bandung : Alfabeta

Muh. Zaidi Thahir. (2017). Efektivitas Penerapan Metode Pembelajaran Brainstorming Terhadap Hasil Belajar Peserta Didik Kelas V Mi Muhammadiyah Pannampu Makassar (skripsi) Universitas Islam Negeri Alauddin Makasar. https://repositori.uin-

alauddin.ac.id diakses pada 17 April 2021

Rama Wahyu Rusinto. (2019). Efektivitas Menggunakan Teknik Simulation Game Berbasis Permainan Roda Berputar Untuk Meningkatkan Rasa Percaya Diri Siswa Kelas XI Ips 2 Di Sma Negeri 1 Grogol Tahun 2017/2018 https://simki.unpkediri.ac.id diakses pada 3 April 2021

Sri Ayu Maharani, Linda Ratna Wati, Yuseva Sariati .(2019). Perbandingan Efektivitas Metode Brain Storming Dan Simulation Game Terhadap Peningkatan Pengetahuan Kanker Payudara Pada Siswi Kelas XII SMAN 4 Malang : https://joim.ub.ac.id. diakses pada: 15 Maret 2021

Sri Lestari Kartikawati. (2016). Hubungan tingkat stres dengan siklus menstruasi pada mahasiswa kebidanan tingkat III ( remaja akhir usia 18-21 tahun) Di stikes Bhakti Kencana Bandung tahun 2016 : https://scholar.google.co.id diakses pada 2 April 2021

Yuni, E, N .(2015). Buku Saku Personal Hygiene GEN, Yogyakarta : Nuha Medika 